\title{
The Analysis of Investment Gap in Rural Road Maintenance: A Case Study of Developing Country
}

\author{
Pujan Neupane ${ }^{1}$ Kat Thida ${ }^{2}$ Phonethida Phommasone ${ }^{3}$ and Chunho Yeom ${ }^{4}$ \\ ${ }^{1}$ Engineer, Ministry of Urban Development, Nepal \\ ${ }^{2}$ Officer, Ministry of Tourism, Cambodia \\ ${ }^{3}$ Technical Officer, Ministry of Public Works and Transport, Lao PDR \\ ${ }^{4}$ Ph.D., Professor, University of Seoul, South Korea
}

\begin{abstract}
Many countries are having an investment gap in public infrastructure; so, there is a tendency among governments to avoid adequate maintenance. With the aging of the infrastructures, the governments are also facing additional challenges and consequences from the maintenance funding gap. This paper examines the current scenario of government expenditure on rural road maintenance in developing countries. In particular, this research examines the need of increasing the maintenance budget and provides recommendations for decision-makers to prioritize the projects. Based on the analysis of 61 rural road maintenance projects, it shows that there is a gap between the required maintenance budget and the government expenditure in maintenance to maintain the standard of the road on different pavement surfaces: Earthen, Gravel, and Bituminous (Premix Carpet, and Otta Seal). This paper also shows the trends of low-cost bidding in a maintenance contract and identifies its impacts on the execution of the works. Finally, this paper highlights the importance of increasing the maintenance budget rather than spending most of the budget on new road construction.
\end{abstract}

Keywords:- Investment Gap; Maintenance; Public Investment.

\section{INTRODUCTION}

The infrastructure funding gap is the major issue in most of the countries. Most of the projects are selected based on the initial investment rather than conducting rigorous life cycle cost analysis. Projects are not selected for economic return but for the political gains and to keep the respective constituency happy. Even though the maintenance is directly linked to project performance, it is usually getting low priority in public investment. In developing countries, the fund allocated for road maintenance has been insufficient creating the maintenance backlogs. The total cost needed for the maintenance of $38,527 \mathrm{Km}$ of the road in Cambodia is $\$ 58$ million, however, the government expenditure is only $\$ 7.7$ million [1]. Similarly, In Lao PDR the cost for maintenance of $31,210 \mathrm{~km}$ of road is $\$ 55$ Million, but the allocated budget is only $\$ 19$ million [1]. In developing countries, the government has an annual capital investment of 2-3\% of GNP in new road construction, but the expenditure on maintenance is low. However, developed countries, like New Zealand spend almost $45 \%$ of their total road budget in maintenance [1]; therefore, the roads in the developing countries are deteriorating at an alarming rate and imposing an unnecessary cost to users. So, this paper aims to address the present status of rural road maintenance in the developing countries, identifies the maintenance gap, studies the benefits of increasing maintenance budget allocation. Finally, it aims at providing the advantages of road maintenance to decision-makers and concerned stakeholders for efficient public investment. This study is divided into two parts: 1) to present the current investment of rural road maintenance in Nepal and to find the maintenance gap. 2) to present the comparative analysis between a cost estimate and contract amount. 3) to emphasize the advantage of road maintenance. The current study investigates the maintenance scenario of the rural roads in Nepal.

\section{LITERATURE REVIEW}

The purpose of maintenance is to preserve the asset, rather than upgrade it. Although the need for maintenance is widely recognized, it is still not getting adequately done. Road authorities often allocate a fixed budget based on an inventory that quantifies the assets in terms of age, length, area, or volume, so the road in many parts of the world is poorly managed and badly maintained. The poor road condition occurred in the large backlog of deferred maintenance. In Africa, \$43 billion was used to restore all roads that classify as a poor condition. In Latin America and the Caribbean, the government spent $\$ 2.5$ billion per year to eliminate the accumulation and obstruct future maintenance [2]. Also, in Kazakhstan, the accumulated backlog is $\$ 1.8$ billion, while in Russia pending $\$ 4.5$ billion per year in the federal highway network alone over an unspecified period. The backlog has become more important in industrial economies [2]. For an instant, a survey in 1996 by the U.K. Institution of Civil Engineers established that there was a $\$ 5.61$ billion maintenance backlog on the local road in Great Britain or $96 \%$ of the total public network [2]. Many countries paid less concentrate on maintenance in the past two decades, the large amount of money invested on road has been decayed [2]. However, the importance of adequate road maintenance in developing countries like Nepal has not been studied.

In developing countries, the maintenance projects are usually awarded to the lowest bidder and the qualifications criteria do not give other considerations such as technical evaluation and litigation history of the bidders. In an early study conducted [3], the research found that projects 
awarded only to the lowest bidders had, in general, a lower performance. Many authors have criticized selecting contractors by considering the lower price as a criterion $[4,5,6]$. They collectively argued that the serious problems which arise within the construction phase because accepting the lowest bid can lead to serious overrun in time and cost, serious quality problems, and eventually to increased litigation.

The importance of addressing road maintenance has been raised and clarified by consequences [7]. It is acknowledged that roads enhance mobility, taking people out of isolation and therefore, poverty. For example, the World Bank has assessed the 85 countries receiving support for their roads, and found that the cost of re-construction has ranged between three and four times the cost of the preventative maintenance that should have been carried out earlier [8]. In its study on road policy, the World Bank estimated that $\$ 45$ billion worth of road infrastructure had been lost due to the absence of adequate maintenance in those 85 developing countries. The study also suggested that such a loss could easily have been avoided by spending $\$ 12$ billion (or the equivalent of $25 \%$ of the impact of the lack of maintenance) on preventative maintenance [9].

Users primarily bear the economic cost of poor road maintenance. When a road is damaged and face with a worse condition, then Vehicle Operation Cost (VOC) will increase from \$2 to \$3 [7]. Most countries spend only 20-50 percent of what the road needs on maintenance [6]; finally, it will face the cost of economy. African spend about 1.2 billion per year extra cost due to insufficient maintenance, which is equivalent to 0.85 percent of regional GDP. While Latin American and the Caribbean additional costs were estimated at $\$ 1.7$ billion per year in 1992 or 1.4 percent of each country's GDP [2]. About 75 percent of these additional VOCs in developing and transition economies must be paid with scarce foreign exchange. The Ministry of Surface Transport in India The Ministry of Surface Transport in India 4 billion of the roughly 39 billion in annual VOCs were saved through sufficient road maintenance, [10]. It is no surprise that road maintenance and rehabilitation projects produce economic rates of return above 35 percent [2].

In 33 countries, maintenance has a significant impact on benefit-cost annually. The maintenance annualized benefit-cost ratios from 1.4 to 44.8 . Moreover, it also can save the operation cost at least $\$ 1.4$ in operating costs and save as much as $\$ 44$ depending on traffic volume if each dollar is spent annually on patching and overlay. Besides, a Russian study shows trucks riding on maintenance road will reduce vehicle life and increase Vehicle Operation Costs by $30 \%$ [2].

According to Ibraheem and Gani (2014), there is a strong correlation between the road surface condition (such as rutting, smoothness, roughness, potholes) and the VOCs [11]. So, leaving the surface of the road without treatment will lead to a substantial increase in the VOCs, and the economic investigation into road maintenance indicates that the implementation of maintenance programs leads to high rates of investment profit. Previous studies on road maintenance are published over the last two decades. Also, the previous studies on road maintenance do not provide, enough evidence on the level of maintenance, and bidding trends in developing countries on different surfaces such as Earthen, Gravel, and Bituminous. So, this study tries to fill those knowledge gaps by providing information on the current situation of road maintenance in developing countries.

\section{METHODOLOGY}

This section describes the method for the assessment of rural road maintenance in the context of developing countries. The data for analysis was primarily collected for the specific study on rural road maintenance in the context of Nepal to emphasize the importance of rural road maintenance. First, the necessary data collection format was developed. The data collection format consists of information on the classification of Road, wearing surface, initial project cost, estimated amount for routine and periodic maintenance, and final contract amount. The data for analysis was obtained from the projects implemented under the Government of Nepal. In this study, the information was collected for 61 projects that have incorporated the maintenance work. The sample data consists of rural roads from 17 districts of the Eastern part of Nepal which includes 12 Earthen Road, 45 Gravel Road, and 4 Bituminous Road. The terrain for the selected roads can be classified into "Teria" and "Hill" based on the topography of the country. Generally, the terrain has a cross slope of 0 to 25 percent is rolling terrain, however, the land having terrain slope from 25 to 60 percent and more is hill roads. The road is a single lane of $3.5 \mathrm{~m}$, and the surface types are Earthen, Gravel, and Bituminous (Premix Carpet $\&$ Otta Seal). The roads are low volume roads with the traffic of fewer than 100 vehicles per day. The data are also collected to evaluate the present government spending on road maintenance, to identify the investment gap between road maintenance provided, and to analyze the impact of an increased budget in the road maintenance.

\section{DATA ANALYSIS}

The data collected is classified into three categories of a rural road based on the wearing course of the road (Earthen, Gravel, and Bituminous). For, the analysis of the rehabilitation period for a rural road is considered as five years from the construction, and after the five years the road must be upgraded or improved. It is found from the data collection that the government spending in the routine maintenance is the same for every road irrespective of the terrain. The budget allocated for routine maintenance is $\$$ 1136 per $\mathrm{km}$ per year for roads in Terai terrain and $\$ 1200$ per $\mathrm{km}$ per year for roads in the Hilly Terrain regardless of surface type. The total government spending on road maintenance before rehabilitation is calculated considering only the budget allocated for Routine and Periodic Maintenance. 
During the analysis, the initial project cost is the total initial cost of individual projects. Since the public entity executes the periodic maintenance through competitive bidding; therefore, the total contract amount of individual project, collected from the data collection, is the total budget allocated for periodic maintenance for five years. The yearly periodic maintenance budget is calculated by dividing the total contract amount of periodic maintenance into five equal installments based on the assumptions that there will be the same expenditure every year. Similarly, the government spends \$ 1136 per km per year in Terai terrain and $\$ 1200$ per $\mathrm{km}$ per year in the Hilly terrain for Routine Maintenance. It is observed from the data analysis as shown in Table I, the government maintenance expenditure for Earthen, Gravel, and Bituminous roads are 5.49\%, 3.30\%, and $1.58 \%$ per year in comparison to the initial project cost. However, on average, the government has allocated $3.48 \%$ of the budget every year for rural road maintenance with respect to the initial project cost.

\begin{tabular}{|c|c|c|c|c|c|}
\hline Type & $\begin{array}{c}\text { No of } \\
\text { Projects }\end{array}$ & $\begin{array}{c}\text { Length } \\
\mathbf{( K m )}\end{array}$ & $\begin{array}{c}\text { Initial Project } \\
\text { Cost (\$) }\end{array}$ & $\begin{array}{c}\text { Total Maintenance } \\
\text { Budget per Year (\$) }\end{array}$ & $\begin{array}{c}\text { \% of Maintenance Budget } \\
\text { Expenditure Per Year with } \\
\text { respect to initial cost Initial } \\
\text { Project Cost }\end{array}$ \\
\hline Earthen Road & 12 & 203.84 & $12,188,980.00$ & $668,867.31$ & $5.49 \%$ \\
\hline Gravel Road & 45 & 654.87 & $52,389,959.20$ & $1,731,355.79$ & $3.30 \%$ \\
\hline Bituminous Road & 4 & 53.84 & $8,076,000.00$ & $127,690.41$ & $1.58 \%$ \\
\hline Total & $\mathbf{6 1}$ & $\mathbf{9 1 2 . 5 6}$ & $\mathbf{7 2 , 6 5 4 , 9 3 9 . 2 0}$ & $\mathbf{2 , 5 2 7 , 9 1 3 . 5 2}$ & $\mathbf{3 . 4 8 \% ( A v e r a g e )}$ \\
\hline
\end{tabular}

Table 1:- Government Maintenance Budget Expenditure

\begin{tabular}{|c|c|c|c|c|c|}
\hline Type & $\begin{array}{c}\text { Maintenance } \\
\text { Budget per km } \\
\text { per Year (\$) }\end{array}$ & $\begin{array}{c}\text { Routine Maintenance } \\
\text { Budget Per Km Per } \\
\text { Year (\$) }\end{array}$ & $\begin{array}{c}\text { Periodic Maintenance } \\
\text { Budget Per Km Per } \\
\text { Year (\$) }\end{array}$ & $\begin{array}{c}\text { \% of Routine } \\
\text { Maintenance }\end{array}$ & $\begin{array}{c}\text { \% of Periodic } \\
\text { Maintenance }\end{array}$ \\
\hline Earthen Road & $3,281.27$ & 1,200 & $2,081.27$ & $36.57 \%$ & $63.43 \%$ \\
\hline Gravel Road & $2,643.79$ & $1,150.37$ & $1,493.42$ & $43.51 \%$ & $56.49 \%$ \\
\hline Bituminous Road & $2,371.66$ & $1,161.05$ & $1,609.13$ & $48.18 \%$ & $51.82 \%$ \\
\hline
\end{tabular}

Table 2:- Government Expenditure on Routine and Periodic Maintenance

On average, the government has allocated an average annual maintenance budget of \$ 3281.27 per km per year for the maintenance of Earthen rural roads in Nepal. The budget allocated is $36.57 \%$ for routine maintenance and $63.43 \%$ for periodic maintenance as shown in Table II. Similarly, the average annual budget allocated for Gravel road maintenance is $\$ 2643.79$ per $\mathrm{km}$ per year. The weightage for routine maintenance is $43.51 \%$ and $56.49 \%$ for periodic maintenance for a gravel road. Likewise, the average annual maintenance budget allocated for bituminous pavement is $\$ 2371.66$ per $\mathrm{km}$ per year among which $48.18 \%$ is allocated for routine maintenance and $51.82 \%$ is allocated for periodic maintenance. Overall, the average annual maintenance budget allocated for routine maintenance and periodic maintenance is $42.75 \%$ and $57.25 \%$ respectively.

The routine maintenance is usually a labor-intensive. The routine maintenance is usually carried out by length workers. They are provided with simple hand tools and construction materials that are supplied by the Local Road User Committee (LRUC). It is observed that there is no competitive bidding for routine maintenance, and the LRUC is usually paid as per their performance based on certain performance indicators. However, for the periodic maintenance, the government of Nepal invites bids from eligible bidders. Table III shows that on an average contractor are bidding as low as $24.09 \%, 26.02 \%$, and $15.53 \%$ below the approved estimated amount for earthen, gravel, and bituminous road respectively. On one hand, this competitiveness is saving government expenditure in rural road maintenance, but on the other hand, it is creating a challenge for the project implementation office to achieve the quality of maintenance.

The annual cost of maintaining a road is small compared to its initial construction cost, usually some $2-3 \%$ for a major paved road and 5-6\% for an unpaved rural road [1]. If the minimum investment necessary for paved and unpaved road maintenance is considered as $3 \%$, and $6 \%$ of the initial cost per year respectively, the maintenance gap is calculated as shown in Table IV. The figure clearly shows the investment gap in rural road maintenance in the context of Nepal. The maintenance gap for Earthen, Gravel, and Bituminous Roads is $\$ 306.45, \$ 2156.20$, and $\$ 2128.336$ per $\mathrm{km}$ per year respectively. On average, the maintenance gap in the context of Nepal can be observed as \$ 1530.332 per $\mathrm{km}$ per year. 
ISSN No:-2456-2165

\begin{tabular}{|c|c|c|c|}
\hline Type & $\begin{array}{c}\text { Approved Cost } \\
\text { Estimated } \\
\text { Amount (\$) }\end{array}$ & $\begin{array}{c}\text { Approved } \\
\text { Contract } \\
\text { Amount (\$) }\end{array}$ & $\begin{array}{c}\text { \% Below on } \\
\text { Contract }\end{array}$ \\
\hline Earthen Road & $2,505,734.25$ & $2,121,272.57$ & $-15.53 \%$ \\
\hline Gravel Road & $6,609,335.13$ & $4,890,036.05$ & $-26.02 \%$ \\
\hline Bituminous Road & $9,669,666.83$ & $7,342,144.70$ & $-24.09 \%$ \\
\hline
\end{tabular}

Table 3:- Comparative Analysis between Cost Estimate \& Contract Amount

\begin{tabular}{|c|c|c|c|}
\hline Types & $\begin{array}{c}\text { Required } \\
\text { Maintenance } \\
\text { Cost for Full } \\
\text { (Per Km/Year) }\end{array}$ & $\begin{array}{c}\text { Allocated } \\
\text { Budget } \\
\text { (Per } \\
\text { Km/Year) }\end{array}$ & $\begin{array}{c}\text { Maintenance } \\
\text { Gap (Per } \\
\text { Km/Year) }\end{array}$ \\
\hline Earthen Road & $3,587.73$ & $3,281.271$ & 306.459 \\
\hline Gravel Road & 4.800 .00 & $2,643.798$ & $2,156.20$ \\
\hline $\begin{array}{c}\text { Bituminous } \\
\text { Road }\end{array}$ & $4,500.00$ & $2,371.664$ & $2,128.336$ \\
\hline Average & $4,295.91$ & $2,765.57$ & $1,530.332$ \\
\hline
\end{tabular}

Table 4:- The Maintenance Gap

\section{CONCLUSION AND RECOMMENDATION}

The study of rural road maintenance of Nepal reflects that the investment in road maintenance is still limited in developing countries. There is a huge budget gap in the maintenance, so it is suggested that the government should increase its current road maintenance investment by at least $35.62 \%$ per year to achieve a certain performance standard. It is also observed that if the government invests additional $\$ 1530.332$ per km per year, the life-cycle cost of the project is reduced, and the rehabilitation period is prolonged. Similarly, the tendency of low bidding in the maintenance contracts has witnessed the failure due to financial problems of contractor, poor performance, lack of adequate quality control. Most of the present system on the maintenance contract awarding system in developing countries are based on price competitiveness, so, to achieve the best result for the public investment and performance of the road, there should be a quality cost trade-off. The contractor selection should be based on technical evaluation together with financial evaluation for effective and reliable maintenance. In addition to these, this study recommends the stakeholders and decision-makers to prioritize and select the projects considering rigorous cost-benefit analysis considering both upfront cost and operating cost for sustainability in budget allocation. Since maintenance projects generate value for the money, and the impact of maintenance has a significant impact on the socio-economic aspects of the country, the investment in the maintenance should be analyzed inconsideration with greenfield projects while formulating plans, policies, and allocating budget for efficient public investment. The database used in this paper is restricted to 61 projects, however, further researches and works are needed to determine the accurate advantages of increasing maintenance budgets in developing countries.

\section{ACKNOWLEDGMENT}

The authors are grateful to the Project Implementation Offices of the Government of Nepal for providing the data to complete this research work.

\section{REFERENCES}

[1]. Ch. Donnges, G. Edmonds, and B. Johannessen,"Rural Road Maintenance - Sustaining the Benefits of Improved Access (SETP 19)," International Labour Office, Bangkok, 2007.

[2]. Ian G. Heggie, and P. Vickers, "Commercial Management and Financing of Roads," In Technical Paper 409, World Bank, Washington, DC, 1998

[3]. R. A. Aitah, "Performance study of the lowest bidder bid awarding system in government projects," Unpublished MS thesis, Department of Engineering, King Fahd University of Petroleum and Minerals, 1988.

[4]. Z. Hatush, and M. Skitmore, "Contractor selection using multicriteria utility theory: an additive model," In Building and Environment, 33(2-3), 1998, p.105115 .

[5]. A. Stein, P. Hawking, and D. C. Wyld, " The $20 \%$ solution: a case study on the efficiency of reverse auctions. Management Research News," 26 (5), 2003, p. $1-20$

[6]. K. Al-Reshaid, and N. Kartam, "Design-build prequalification and tendering approach for public projects," In International Journal of Project Management, 23 (4), 2005, p. 309-320. 
[7]. C. Parkman, K. Madelin, and R. Robinson," Managing Change to Improve The Delivery Of Road Maintenance, 2000.

[8]. S. Adling, and A. Gupta, “ Pavement Deterioration and its Causes," In Mechanical and Civil Engineering, 2009, p. 9-15.

[9]. D. V. Hiep, "PhD Thesis Optimisation of Pavement Designs and/or Maintenance Strategies using Gradient Search with Option Evaluation Systems," In Engineering, 2009, p.134.

[10]. Indian Ministry of Surface Transport. Unpublished country paper presented at ESCAP/World Bank conference on a "Management and Financing of Roads in the ESCAP Region", Bangkok, September, 1996.

[11]. A. Ibraheem, and S. Gani, "Evaluation of Common Maintenance Methods for Flexible Pavements," American Journal of Engineering and Applies Sciences, 4(3), 2014, p.413-424. 